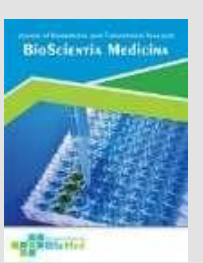

Bioscientia Medicina: Journal of Biomedicine \& Translational Research

Journal Homepage: www.bioscmed.com

\title{
Characteristics of Endometriosis Patients in Dr. Mohammad Hoesin General Hospital on 2018 to 2020
}

\author{
Ratu Tenny Leriva ${ }^{*}$, Iskandar Zulqarnain ${ }^{2}$, Hadrians Kesuma Putra², Awan Nurtjahyo², Syifa Alkaf ${ }^{2}$ \\ ${ }^{1}$ Medical Education Study Program, Faculty of Medicine, Universitas Sriwijaya, Palembang, Indonesia \\ ${ }^{2}$ Department of Obstetrics and Gynecology, Dr. Mohammad Hoesin General Hospital, Palembang, Indonesia
}

\section{A R T I C L E I N F O}

\section{Keywords:}

Endometriosis

Gynecology

Observational study

Descriptive study

Dysmenorhea

\section{*Corresponding author: \\ Ratu Tenny Leriva \\ E-mail address: \\ Lerivahd@gmail.com}

All authors have reviewed and approved the final version of the manuscript.

https://doi.org/10.37275/bsm.v6i4.478

\begin{abstract}
A B S T R A C T
Background. Endometriosis is defined as the presence of endometrial-like tissue outside the uterus. The prevalence of endometriosis is not known with certainty because it is necessary to perform a laparoscopy to confirm the diagnosis of endometriosis and is usually found during examination for other indications. This study aims to explore the characteristics of endometriosis patients at Dr. Mohammad Hoesin General Hospital Palembang. Methods: This research is descriptive observational research. The research data were obtained from the medical records of endometriosis patients treated at Dr. Mohammad Hoesin General Hospital Palembang from 2018 to 2020. Results: Of the 105 sample data studied, the most distribution of endometriosis patients was in the reproductive age group (15-49 years) (99\%), menarche $12-14$ years $(67.6 \%)$, the location of endometriosis in the ovaries $(58.1 \%)$, status indoor workers $(99 \%)$, marital status $(85.7 \%)$, fertile $(43.8 \%)$, and infertile patients $(41.9 \%)$, the chief complaint of dysmenorrhea $(66.7 \%)$, stage IV disease $(63,8 \%)$, nullipara $(60 \%)$, surgical management $(79 \%)$. Conclusion: Most of the characteristics of endometriosis patients were in the reproductive age group (15 - 49 years), menarche 12-14 years, endometriosis location in the ovary, indoor worker status, marital status, infertility, the main complaint of dysmenorrhea, stage IV disease, nullipara, surgical treatment.
\end{abstract}

\section{Introduction}

Endometriosis is defined as the presence of endometrial-like tissue outside the uterus. In general, endometriosis is found mostly in the pelvic peritoneal area but is also found in other frequently occurring sites including the ovaries and the uterosacral ligaments. ${ }^{1}$ Exactly, the pathophysiology of endometriosis has not been determined but the hormone estrogen is thought to have a role in the increasing number of cases of endometriosis which is driven by the available evidence ${ }^{2}$.

Most women with endometriosis are found to have no symptoms. However, endometriosis may be suspected in women with chronic pelvic pain, dysmenorrhea, dyspareunia, and subfertility. Supportive examination of endometriosis can be done by magnetic resonance imaging (MRI), ultrasonography (USG), anatomical pathology examination, and serum CA125 examination. While that is used in the diagnosis of endometriosis is laparoscopy. ${ }^{1}$

The prevalence of endometriosis is not known with certainty because laparoscopy is necessary to confirm the diagnosis of endometriosis and is usually found 
during examination for other indications. ${ }^{3}$ However, from the data found in several hospitals in Indonesia, the incidence of endometriosis at Dr. Hospital. Cipto Mangunkusumo around 69.5\%, Regional General Hospital Dr. Moewardi around 13.6\%, and Regional General Hospital Dr. Soetomo around 37.2\%. 3,4 Currently, endometriosis staging is classified according to the American Society For Reproductive Medicine (ASRM) which is assessed based on location, shape, type, lesion infiltration, spread, and adhesion. Then the classification according to ASRM includes 4 stages; stage I, stage II, stage III, and stage IV. ${ }^{1}$

Management of endometriosis can use medical and surgical treatment options. The use of oral contraceptives, a combination of a GnRH agonist plus an aromatase inhibitor is used for pain relief 5 . Surgical treatment of endometriosis is classified as conservative or definitive therapy. Conservative surgery includes cauterization, excision technique, or ablation of visible endometriotic lesions. Repair of anatomical abnormalities, and preparation of reproductive organs to maintain the chance of getting pregnant in the future. 6 Treatment Definitive surgery includes bilateral salpingo-oophorectomy, total hysterectomy, and removal of all nests of endometriosis lesions found. ${ }^{7}$

Based on the information above, endometriosis is a disease that has non-specific symptoms and can only be diagnosed using laparoscopic techniques. Diagnosis carried out quickly and accurately is needed to prevent complications in cases of endometriosis. This study aims to explore the characteristics of endometriosis patients at Dr. Mohammad Hoesin General Hospital Palembang.

\section{Methods}

The research was conducted using a descriptive observational method. This study uses secondary data in the form of medical records of endometriosis patients at Dr. Mohammad Hoesin General Hospital Palembang in 2018-2020. This research was conducted in the medical records department of the Department of Obstetrics and Gynecology, Dr. Mohammad Hoesin Palembang. The total sampling method was used for sampling this research.

Medical record data of patients who have been diagnosed with endometriosis at the Department of Obstetrics and Gynecology, Dr. Mohammad Hoesin Palembang who met the inclusion criteria. The inclusion criteria in this study were all medical record data of patients who had been diagnosed with endometriosis by a specialist in obstetrics and gynecology using surgical techniques (laparoscopy/laparotomy) at the Department of Obstetrics and Gynecology, Dr. Mohammad Hoesin Palembang Period 2018 - 2020 with complete medical record data. This research has been approved by the ethics committee of the Sriwijaya University Faculty of Medicine (Ref. No. 211-2021). The research variables to be studied were age, menarche, location of endometriosis, occupation, marital status, infertility status, chief complaint, stage of disease, parity, and treatment of endometriosis.

Secondary data will be analyzed descriptively using the SPSS for Windows program. Data that has been processed and analyzed univariately is presented in tabular form and explained narratively.

\section{Results}

The total research sample obtained in this study was 105 people. Table 1 shows the baseline characteristics of all endometriosis patients. The majority of patients are in the productive age group 1549 years (99\%) and are active in an indoor environment (99\%). Patients experienced the age of menarche at the age of 12-14 years (67.6\%). Based on marital status, the majority of patients were married (85.7\%), fertile (43.8\%), and parity status was nulliparity (60\%). The main complaint commonly experienced by the majority of endometriosis patients in this study was dysmenorrhea (66.7\%). Patients who go to Dr. Mohammad Hoesin General Hospital had the most stage IV endometriosis (63.8\%). Based on the treatment obtained, most of the endometriosis patients underwent surgery (79\%). 
Table 1. Distribution of endometriosis patients

\begin{tabular}{|c|c|c|}
\hline Characteristics & Total (n) & Percentage (\%) \\
\hline $\begin{array}{l}\text { Age } \\
\qquad \begin{array}{l}15-49 \text { years old } \\
15-24 \text { years old } \\
25-35 \text { years old } \\
36-45 \text { years old } \\
46-49 \text { years old } \\
\geq 50 \text { years old }\end{array}\end{array}$ & $\begin{array}{c}104 \\
4 \\
64 \\
33 \\
3 \\
1\end{array}$ & $\begin{array}{c}99 \\
3,8 \\
61 \\
31.4 \\
2.9 \\
1\end{array}$ \\
\hline $\begin{array}{l}\text { Menarche } \\
\quad \leq 11 \text { years } \\
12-14 \text { years } \\
\geq 14 \text { years } \\
\end{array}$ & $\begin{array}{c}4 \\
71 \\
30\end{array}$ & $\begin{array}{l}3.8 \\
67.6 \\
28.6\end{array}$ \\
\hline $\begin{array}{l}\text { Occupation } \\
\text { Indoor (office employees, students) } \\
\text { Outdoor (farmer) }\end{array}$ & $\begin{array}{c}104 \\
1\end{array}$ & $\begin{array}{c}99 \\
1\end{array}$ \\
\hline $\begin{array}{l}\text { Marital status } \\
\text { Married } \\
\text { Unmarried }\end{array}$ & $\begin{array}{l}90 \\
15\end{array}$ & $\begin{array}{l}85.7 \\
14.3\end{array}$ \\
\hline $\begin{array}{l}\text { Infertility status } \\
\text { Fertile } \\
\text { Infertile } \\
\text { Unmarried } \\
\end{array}$ & $\begin{array}{l}46 \\
44 \\
15\end{array}$ & $\begin{array}{l}43.8 \\
41.9 \\
14.3\end{array}$ \\
\hline $\begin{array}{l}\text { The main complaint } \\
\text { Dysmenorrhea } \\
\text { Pelvic pain } \\
\text { Dyspareunia }\end{array}$ & $\begin{array}{c}70 \\
34 \\
1\end{array}$ & $\begin{array}{c}66.7 \\
32.4 \\
1.0\end{array}$ \\
\hline $\begin{array}{l}\text { Stage of disease } \\
\text { Stage I } \\
\text { Stage II } \\
\text { Stage III } \\
\text { Stage IV }\end{array}$ & $\begin{array}{c}10 \\
6 \\
22 \\
67\end{array}$ & $\begin{array}{l}9.5 \\
5.7 \\
21.0 \\
63.8\end{array}$ \\
\hline $\begin{array}{l}\text { Parity } \\
\text { Nulliparity } \\
\text { Primiparity } \\
\text { Multiparity } \\
\end{array}$ & $\begin{array}{l}63 \\
15 \\
27\end{array}$ & $\begin{array}{c}60 \\
14.3 \\
25.7\end{array}$ \\
\hline $\begin{array}{l}\text { Treatment } \\
\text { Medications } \\
\text { Surgery } \\
\text { Surgery and adjuvant treatment }\end{array}$ & $\begin{array}{c}13 \\
83 \\
9\end{array}$ & $\begin{array}{l}12.4 \\
79.0 \\
8.6\end{array}$ \\
\hline
\end{tabular}

The results of the study on the distribution of patients based on the location of endometriosis are shown in table 2. It can be seen that the distribution of endometriosis locations is divided into the uterus, ovaries, fallopian tubes, uterosacral ligaments, da $\mathrm{n}$ peritoneum. The table shows the location of endometriosis found in patients with endometriosis at Dr. Mohammad Hoesin General Hospital Palembang on the ovaries as many as $61(58.1 \%)$, then followed by the location in the uterus as many as 28 (26.7\%). In this study, endometriosis patients were found with more than one location (multiple).

Table 2. Distribution of endometriosis patients by location of endometriosis

\begin{tabular}{|c|c|c|c|c|c|c|}
\hline Location of & Uterus & Ovary & Fallopian & $\begin{array}{c}\text { Tube } \\
\text { Uterosacral } \\
\text { Ligament }\end{array}$ & Peritoneum & Colon \\
\hline & $\mathbf{n}(\%)$ & $\mathbf{n}(\%)$ & $\mathbf{n}(\%)$ & $\mathbf{n}(\%)$ & $\mathbf{n}(\%)$ & \\
\hline No & 76 (72.4) & $44(41,9)$ & $90(85.7)$ & $103(98.1)$ & $103(98.1)$ & 104 (99) \\
\hline Yes & $29(27.6)$ & $61(58.1)$ & $15(14.3)$ & $2(1.9)$ & $2(1,9)$ & $1(1)$ \\
\hline Total & $105(100)$ & $105(100)$ & $105(100)$ & $105(100)$ & $105(100)$ & $105(100)$ \\
\hline
\end{tabular}




\section{Discussion}

Based on the results of the study, the patient characteristics based on age were found in the majority of 104 patients (99\%) are included in the reproductive age group, namely 15-49 years, and in this study 1 patient was found in the non-reproductive age group, namely $>49$ years $(1 \%)$. This is related to the theory that the incidence of endometriosis is mostly found in women of reproductive age and is not found in postmenopausal women who do not have the hormone estrogen anymore, it is found that hormonal changes will affect the proliferation of endometrial cells attached to the mesothelium and there is no clearance of the body's immune system. This supports the concept that endometriosis is an estrogen-dependent disease. ${ }^{8-15}$

Based on the age of menarche, as many as 71 patients $(67.6 \%)$ experienced menarche at the age of $12-14$ years, followed by menarche $\geq 14$ years as many as 30 patients $(28.6 \%)$, and patients with menarche $\leq 11$ years as many as 4 patients $(3.8 \%)$. This is not following the statement of Wei et al., where women with menarche at an early age, will first receive hormonal changes that can increase the risk of endometriosis. ${ }^{16}$

The results of the study regarding the distribution of patients based on the location of endometriosis showed that the majority of the distribution of patients with endometriosis was based on the location of endometriosis in Dr. Mohammad Hoesin Palembang on the ovaries as many as $61(58.1 \%)$, then followed by the location in the uterus as many as $28(26.7 \%)$. In this study, it was found that patients with endometriosis had more than one location (multiple), especially those with severe endometriosis. In retrograde menstruation theory, there is a backflow of menstrual blood containing endometrial tissue through the fallopian tubes during menstruation. This refluxed endometrial fragment invades the peritoneal mesothelium and develops a blood supply for implantation survival and growth. This mechanism is often associated with the incidence of pelvic endometriosis and the incidence of ovarian endometriosis. ${ }^{11}$

In a study on the distribution of endometriosis patients based on occupational status, 104 patients (99\%). While patients who work outdoors as much as 1
(1\%). Outdoor workers are more often exposed to sunlight than indoor workers. This is related to the study of Miyashita, et al., who found significantly lower levels of vitamin D3 in severe endometriosis compared with normal control patients and patients with mild endometriosis, vitamin $\mathrm{D}$ is produced in the body from food and supplements and exposure to sunlight. against the skin. ${ }^{17}$

The results of the study regarding the distribution of endometriosis patients based on marital status, it was found that the majority of patients were married, namely 90 patients $(85.7 \%)$. This relates to most cases of endometriosis usually found when examined for other indications such as infertility 3 . Based on infertility status, the number of fertile patients was 46 (43.8\%), infertile 44 (41.9\%), and 15 (14.3\%) unmarried. This is in line with the research of Fatima, et al (2018) where the incidence of endometriosis is highest in women who complain of infertility up to 20 $50 \%$ in Arifin Achmad Hospital, Riau Province 9. Adhesion is one of the most intuitive descriptions of infertility associated with endometriosis. Adhesions can also interfere with the uptake and transport of normal oocytes by the fallopian tubes. Apart from mechanical disturbances, a large number of subtle defects also appear to be involved. These defects include disorders of ovulation, sperm release, follicular development, implantation, and embryo quality and development. ${ }^{1}$

In a study on the distribution of endometriosis patients based on their chief complaint, it was found that the majority of endometriosis patients had dysmenorrhea as their main complaint, namely 70 (66.7\%). In this study, 34 patients $(32.4 \%)$ had a primary complaint of pelvic pain and 1 patient $(1 \%)$. Inflammatory cytokines and prostaglandins released by endometriotic implants can be one source. ${ }^{5}$

The results of the study regarding the distribution of endometriosis patients based on the stage of the disease found that the majority of stage IV endometriosis patients were 67 (63.8\%). In this study, there were 22 patients $(21 \%)$, stage III patients $(9.5 \%)$, and stage II patients $(5.7 \%)$. This is related to most cases of endometriosis, usually found during 
examination for other indications, while endometriosis can only be confirmed by laparoscopy. 13 So that most cases of endometriosis are found after an advanced stage.

In a study on the distribution of endometriosis patients based on parity, it was found that the majority of endometriosis patients were nulliparous as many as 63 patients (60\%), then 15 (14.3\%) primiparous patients, and multiparous patients. as many as 27 $(25,7 \%)$. Based on several studies, it was found that there is a relationship between the history of parity and risk factors for endometriosis. ${ }^{18-20}$

In severe and extensive endometriosis, surgical treatment is the main preference because it is known that endometriomas larger than $1 \mathrm{~cm}$ will not shrink when treated medically. The results showed that the majority of treatment for endometriosis patients as many as 83 (79\%) underwent surgery, followed by treatment for medical patients as many as $13(12,4 \%)$, and surgical and adjuvant patient handling as many as $9(8,6 \%)$. Surgical efforts are aimed at the removal of the endometrial implant and correction of anatomic distortions. ${ }^{20}$

Adhesions that occur as a result of endometriosis can interfere with the ovum capture mechanism. Most corrective surgery is performed for patients with endometriosis because repair of anatomic abnormalities is thought to reduce the risk of developing endometriosis. Conservative surgery including cauterization, excision technique, or ablation of endometriotic lesions seen on laparoscopy is performed to correct anatomic abnormalities caused by endometriosis for preparation of reproductive organs to maintain the chances of future pregnancies. In mild endometriosis, medical treatment is a preference. If the incidence of endometriosis is found together with other infertility factors (anovulation, luteal phase defect) occurs, it is advisable to correct other factors first.

\section{Conclusion}

The characteristics of endometriosis patients in this study were the majority of the productive age group 1549 years old, active in an indoor environment, the age of menarche at the age of 12-14 years, marital status, fertility, and nulliparity. The main complaint that is generally experienced by most endometriosis patients in this study is dysmenorrhea. Patients who go to Dr. Mohammad Hoesin General Hospital at most have stage IV endometriosis. Based on the treatment obtained, most of the endometriosis patients underwent surgery. Characteristics of endometriosis patients based on the location of endometriosis found that the majority of endometriosis locations were in the ovary, followed by the uterus, then in the fallopian tubes and followed by the location of endometriosis in the uterosacral and the least was in the peritoneum and had not been found in other locations.

\section{References}

1. Hoffman B. Williams Gynecology 3rd edition. Vol. 1, Statewide Agricultural Land Use Baseline 2015. 2016.

2. Jacoeb TZ, Hadisaputra W. No Title. Treatment of endometriosis: Clinical Guide and Algorithms. 2009.

3. Bulun SE, Yilmaz BD, Sison C, Miyazaki K, Bernardi L, Liu S, et al. Endometriosis. Endocrine Reviews. 2019; 40.

4. Donnez J, Donnez O, Orellana R, Binda MM, Dolmans MM. Endometriosis and infertility. Panminerva Medica. 2016; 58.

5. Advincula A, Truong M, Lobo RA. Endometriosis: Etiology, pathology, diagnosis, management. Comprehensive Gynecology. 2017.

6. Fatimah D, Hutagaol IEB, Romus I. Profile of endometriosis cases at Arifin Achmad Hospital, Riau Province Period 1 January 2012 - 31 December 2016. Journal of Medical Sciences. 2018; 12(1): 42-3.

7. Lukas I, Kohl-Schwartz A, Geraedts K, Rauchfuss M, Wölfler MM, Häberlin F, et al. Satisfaction with medical support in women with endometriosis. PLOS One. 2018; 13(11).

8. Konrad L, Dietze R, Kudipudi PK, Horné F, Meinhold-Heerlein I. Endometriosis in MRKH cases as a proof for the coelomic metaplasia hypothesis? Reproduction. 2019; 158. 
9. Hendarto $H$. Endometriosis from theory aspects to clinical management. Airlangga University Press. 2015; 9-65

10. Davila GW. Endometriosis: Practice essentials, pathophysiology, etiology. Endometriosis. 2017.

11. Wei M, Cheng Y, Bu H, Zhao Y, Zhao W. Length of menstrual cycle and risk of endometriosis a meta-analysis of 11 case-control studies. Medicine (United States). 2016; 95.

12. Burney RO, Guide LC. Pathogenesis and pathophysiology of endometriosis. Fertility and Sterility. 2012; 98.

13. Wu IB, Tendean HMM, Mewengkang ME. Characteristics of endometriosis patients at RSUP Prof. Dr. RD Kandou Manado. e-CliniC. 2017; 5(2).

14. Almassinokiani F, Khodaverdi S, SolaymaniDodaran M, Akbari P, Pazouki A. Effects of vitamin $\mathrm{D}$ on endometriosis-related pain: A double-blind clinical trial. Med Sci Monit. 2016; 22: 4960-6.

15. Miyashita M, Koga K, Izumi G, Sue F, Makabe T, Taguchi A, et al. Effects of 1,25-Dihydroxy vitamin $\mathrm{d} 3$ on endometriosis. J Clin Endocrinol Metab. 2016; 101(6): 2371-9.

16. Suryadinata RV, Lorensia A, Aprilia AP. Profile of vitamin $\mathrm{D}$ in adult asthma and non-asthma patients in Surabaya. Indonesia J Public Heal. 2017; 12(1): 106.

17. Kumar KH, Elavarasi P. Definition of pain and classification of pain disorders. J Adv Clin Res Insights. 2016;3.

18. Oshinowo A, Ionescu A, Anim TE, Lamvu G. Dyspareunia and vulvodynia. In: Pelvic pain management. 2016.

19. Dunselman GAJ, Vermeulen N, Becker C, Calhaz-Jorge C, D'Hooghe T, De Bie B, et al. ESHRE guidelines: Management of women with endometriosis. Hum Reprod. 2014;29(3).
20. Canis M, Donnez JG, Guzick DS, Halme JK, Rock JA, Schenken RS, et al. Revised American society for reproductive medicine classification of endometriosis: 1996. Fertile Sterile. 1997; 67(5). 